九州大学学術情報リポジトリ

Kyushu University Institutional Repository

\title{
A SYNOPSIS OF 'I 'HE BEE GENUS PALAEORHIZA PERKINS (HYMENOPTERA, COLLETIDAE) OF NEW GUINEA . PART VIII. SUBGENUS CALLORHIZA
}

Hirashima, Yoshihiro

https://doi.org/10.5109/2512

出版情報: ESAKIA. 28，pp.1-9，1989-03-03. Entomological Laboratory，Faculty of Agriculture， Kyushu University

バージョン :

権利関係 : 


\title{
A SYNOPSIS OF THE BEE GENUS PALAEORHIZA PERKINS (HYMENOPTERA, COLLETIDAE) OF NEW GUINEA PART VIII. SUBGENUS $C A L L O R H I Z A^{1), 2), 3)}$
}

\author{
Y OSHIHIRO HIRASHIMA \\ Entomological Laboratory, Faculty of Agriculture, \\ Kyushu University, Fukuoka 812, Japan \\ and \\ Hikosan Biological Laboratory, Faculty of Agriculture, \\ Kyushu University, Hikosan 824-07, Japan
}

\begin{abstract}
A new subgenus Callorhiza (type-species: Prosopis apicatus Smith, 1863) of the genus Palaeorhiza Perkins (Hymenoptera, Colletidae) is proposed. Six new species of Callorhiza, i. e., samuelsoni, albopicata, fulvago, attractans, micheneri and agrias, are described from Papua New Guinea. Palaeorhiza disrupta Cockerell, an Australian species, is recorded from Papua New Guinea for the first time.
\end{abstract}

In this paper a new subgenus Callorhiza is described. The type is Prosopis apicatus Smith, 1863, from Misool. This subgenus is a large, heterogenous group including such diverse forms as : Palaeorhiza apicata (Smith), a fulvous species having the long malar space and white markings on the head ; $\mathbf{P}$. flava Cheesman, a fulvous species having the short malar space and yellow markings on the head ; P. turneriana (Cockerell), a robust and entirely metallic species ; P. bagudai Cheesman, a metallic species having white hair bands on the metasomal terga ; P.disnupta Cockerell, a robust and metallic species having rich yellow markings on the head, thorax and legs; P.cylindrica Hirashima, a metallic, yellow-decorated and elongate species ; P. odyneroides Hirashima, a metallic, yellow-decorated and hairy species ; P. callima Hirashima, a metallic and red species ; P. tricolor Hirashima, a black (the head and thorax), red (the metasoma) and yellow (the legs) species ; P.tetraxantha (Cockerell), a small yellow species having black stripes on the thorax ; P. stygica Michener, a black species ; P. falcifera Hirashima et Lieftinck, a black species having the edentate, flaciform mandible ; etc. However, these species are combined into but one subgenus by the characters given below.

1) This paper is dedicated to Professor Charles Duncan Michener, The University of Kansas, Lawrence, Kansas, U. S. A. on the occasion of his seventieth birthday, 22 September 1988.

${ }^{2)}$ Contribution from the Entomological Laboratory, Faculty of Agriculture, Kyushu University, Fukuoka (Ser. 3, No. 289).

3) Contribution from the Hikosan Biological Laboratory, Faculty of Agriculture, Kyushu University, Hikosan (Ser. 3, No. 10). 


\section{Y. HIRASHIMA}

Genus Palaeorhiza Perkins, 1908

\section{Callorhiza, new subgenus}

Type-species : Prosopis apicatus Smith, 1863

Diagnosis : Propodeal enclosure small to large, subdorsal, usually smooth, impunctate and shining ; basal portion of hind tibia normal (unmodified) ; posterior spur of hind tibia normal ; female 6th tergum normal.

Distribution : Australia, Misool, New Guinea and Solomon Islands.

Included species : aenea Hirashima et Lieftinck, 1983, bagudai Cheesman, 1948, bicolorata Hirashima et Lieftinck, 1983, capitata Hirashima et Lieftinck, 1983, cuprea Hirashima, 1988, cylindrica Hirashima, 1975, callima Hirashima, 1988, callimoides Hirashima, 1988, disnupta Cockerell, 1914, eboracina (Cockerell, 1910), eugenes Hirashima, 1988, eugenoides Hirashima, 1988, eumorpha Hira shima, 1988, falcifera Hirashima et Lieftinck, 1983, flavipes Hirashima, 1988, fulva Cheesman, 1948, gloriosa Hirashima et Lieftinck, 1983, heterochroa Hirashima, 1988, infuscata Michener, 1965, jutefae Cheesman, 1948, latifacies Hirashima, 1988, maluae Cheesman, 1948, odyneroides Hirasbma, 1988, paracylindrica Hirashima et Lieftinck, 1983, parva Hirashima, 1975, polita Hirashima et Lieftinck, 1983, senilis Hirashima, 1988, subcrassiceps Hirashima et Lieftinck, 1983, stygica Michener, 1965 , tetraxantha (Cockerell, 1911), tricolor Hirashima, 1988, turneriana (Cockerell, 1905), viridiceps Hira shima et Lieftinck, 1983, and viridimutans (Cockerell, 1916).

In this paper, 6 more species are described as new.

The material on which the present paper is based is derived from the collections of Bishop Museum (Honolulu), Kyushu University (Fukuoka) and University of Kansas (Lawrence).

All the holotypes of new species described in this paper will be deposited in the Bishop Museum.

I am grateful to the late Dr. J. L. Gressitt and Mr. G. Nishida (Bishop Museum) and Prof. C. D. Michener (University of Kansas) for the loan of valuable specimens.

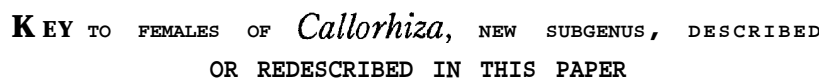

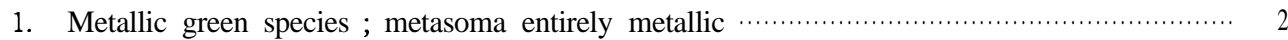

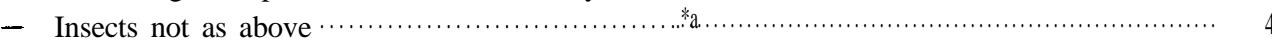

2. Head, thorax and legs with rich yellow markings ; thorax strongly and densely punc-

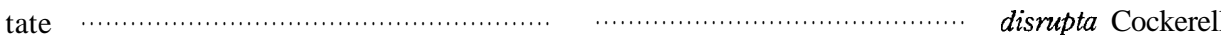

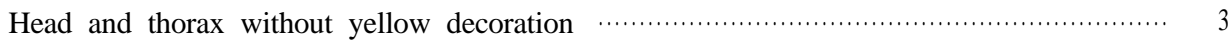

3. Compact species as usual; 1 st and 2 nd terga with snow-white hair bands latero-apically

bagudai Cheesman

Rather slender species with elongate thorax ; 1st tergum low, apical portion transversely concave.. ............................................................... samuelsoni, new species

4. Small species ; metasoma entirely yellow or red (or 6th tergum only slightly darkened in

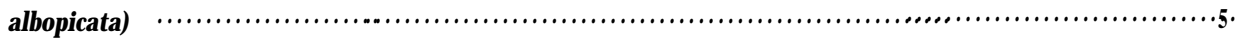

- Larger species; metasoma red with three apical terga dark metallic $\ldots \ldots \ldots \ldots \ldots \ldots \ldots \ldots \ldots .6$.

5. Head and thorax shining black with metallic steel-blue reflection; markings on head

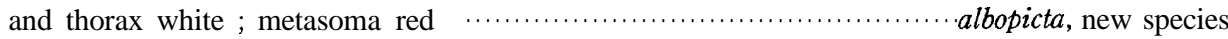

- Head and thorax yellow with black stripes or markings, strongly shining; legs and metasoma yellow, or the latter slightly reddish (fulvous) $\ldots \ldots \ldots \ldots \ldots \ldots \ldots \ldots$ fulvago, new species

6. Head and thorax black (with slight metallic green and coppery tints) with rich yellow 
stripes

attractans, new species

Head and thorax largely yellow or yellow and red

Head and thorax yellow with black (or blackish) markings; propodeal enclosure yellow ; metasoma with three basal terga red (ferruginous) with yellow markings and three

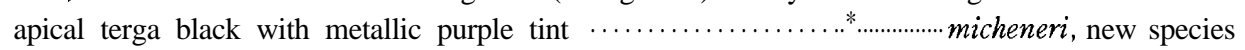
Head and thorax yellow and red, without black marking (except some on top of head) ; propodeal enclosure red as in mesoscutum, scutellum, metanotum and dorsal portion of propodeum lateral to enclosure ; three basal terga largely metallic agrias, new species

\section{Palaeorhiza (Callorhiza) disrupta Cockerell}

Palaeorhiza parallela dismupta Cockerell, 1914, Insect. Inscit., 2 : 98.

Palaeorhiza disrupta is a good species, neither a variety nor a subspecies of P.parallela Cockerell. As Hirashima (1981) pointed out, even Cockerell confused disrupta with parallela. The two species are similar each other in the general habitus and ground coloration (plus yellow decoration), but $\mathbf{P}$. parallela is a member of the subgenus Cnemidorhiza Hirashima, which is characterized by the modification of the 6th tergum and the basal portion of hind tibia in the female (Hirashima, 1981).

Female : Medium-sized, robust species.

Malar space slightly less than half of basal width of mandible, slightly widened posteriorly ; inner eye margins slightly converging below ; supraclypeal area narrowed above, well elevated between antennal bases; space between eye and clypeus broader than anterior portion of malar space ; mesoscutum and scutellum well convex, very densely and strongly punctate ; punctures on the latter usually slightly coarser and sparser than those on the former ; propodeal enclosure rather short. Legs rather robust ; polliniferous hairs on fore tarsi well developed. Metasoma well convex ; terga well punctate ; $\mathrm{n}$ lateral portions of 2 nd and 3rd terga conspicuously punctate ; impunctate apical margins of three basal terga rather broad and well indicated.

Metallic green, with slight to distinct purple and blue reflections on metasoma ; head, thorax and legs with following markings yellow : five stripes on head, entire band on collar of pronotum, mark on axilla, lateral stripes on scutellum (sometimes broad), lateral marks on metanotum (sometimes large or small and rarely absent), mark on tegula, that on tubercle, that on pre-epistemum behind tubercle and basal marks on all tibiae.

Somewhat hairy but hairs short ; hairs on propodeum and three basal terga white ; hairs on apical metasomal segments nearly black.

Male : Similar to female except as follows :

Face narrower and longer ; malar space a little shorter than basal width of mandible ; facial markings ivory, much more developed than in female ; scape ivory in front ; yellow markings on fore tarsi well developed ; metasomal sterna unmodified ; 4th to 6th sterna with long, dense, suberect, blackish hairs.

SPECIMENS EXAMINED : AUSTRALIA : 1 female, Hambledon, Queensland, XI. 1921 (Pemberton), in the collection of Bishop Museum; 2 females, Dunk Island, Queensland, VIII. 1927 (H. Hacker), in the collection of the University of Kansas. PAPUA NEW GUINEA : 2 females, Oriomo Govt. Sta., W. District, 26-28. X. 1960, Malaise trap (J. L. Gressitt) ; 2 females, Brown River, 5 m, 23. X. 1960, by Malaise trap (J. L. Gressitt) ; 1 female, Tapini, Central District, 1,OOO-1,100 m, 18. V. 1961 (J. L. \& M. Gressitt) ; 1 male, Tapini, 9-12. VII. 1968 (Mena); 1 male, Tapini, XI. 1968 (N. L. H. Krauss), in the collection of Bishop Museum; 2 females, Aieme River, Central Province, 5. VI. 1983 (J. W. Ismay), in the collection of Kyushu University.

Distribution : Australia and Papua New Guinea. This is the first record of this species from 


\title{
Y. HIRASHIMA
}

Papua New Guinea.

\section{Palaeorhiza (Callorhiza) bagudai Cheesman}

\author{
Palaeorhiza bagudai Cheesman, 1948, Ann. Mag. Nat. Hist., (12) $1: 321$.
}

This species was described by the male only. Cheesman suspected that this is possibly the male of rectituda Cheesman.

So far as I know, P. bagudai is a very difficult species and the bagudai-complex is composed of several very closely related species. The bagudai-complex will be discussed in a separate paper.

The female of bagudai may easily be distinguished from those of the other congeneric species by the coloration (entirely blue-green with no pale marking on any parts of the body) and the presence of snow-white hair bands on the basal metasomal terga. The malar space is about half as long as the basal width of mandible in the middle.

Specimens examined : Many specimens from Papua New Guinea in the collections of Bishop Museum and Kyushu University.

Distribution : Papua New Guinea.

\section{Palaeorhira (Callorhiza) samuelsoni, new species}

This is a more or less large, beautiful green species having no pale markings on any parts of the body except legs. This species is also very distinctive in having the 1st tergum transversely concave subapically and the 2 nd tergum very strongly constricted basally.

Female : Length about $8 \mathrm{~mm}$; more or less slender.

Relative head measurements : length, 27.0 ; width 31.8 : upper interocular distance, 18.0 ; width of face, 21.2 ; lower interocular (distance, 15.0 ; length of eye, 22.5 ; length of clypeus, 11.8 .

Head rather small for the size of insect ; inner eye margins converging below except upper portions ; face largely flat ; supraclypeal area broad, rather flat, only slightly elevated ; malar space about one-fourth as long as basal width of mandible anteriorly, broadened posteriorly ; vertex weakly convex ; upper portion of supraclypeal area not specially modified.

Thorax rather elongate, nearly cylindrical ; collar of pronotum low ; mesoscutum well convex, especially anteriorly ; scutellum flat ; metanotum rather broad, flat ; propodeum rather long; propodeal enclosure large, almost all dorsal.

Metasoma rather elongate ; 1st tergum low, much lower than 2nd which is strongly constricted at base ; 1st tergum transversely concave subapically ; 2nd sternum constricted at base.

Clypeus more or less coarsely punctate on finely tessellate surface ; frons rather strongly punctate. Mesoscutum densely, rather strongly punctate on smooth, shining ground ; scutellum similar to mesoscutum, but punctures smaller ; metanotum rather shining, microscopically shagreened with minute punctures ; propodeal enclosure rather dull, very finely shagreened ; propodeum outside enclosure rather coarsely sculptured, with rather coarse punctures ; lower portion of mesepistemum polished with sparse, shallow punctures. Metasoma with 1 st tergum very densely, finely punctate, rather dull ; 2nd punctate as in 1.st except lateral portions ; median portion of 3rd also very densely punctate ; 4th not as in the basal three terga, shining, with coarse and sparse punctures ; impunctate apical margin of $2 \mathrm{nd}$ linear, that of $3 \mathrm{rd}$ a little borader, that of.4th broad; sterna strongly punctate.

Brilliant metallic green, including legs ; no pale marking on any part of body except yellowish markings on anterior faces of fore tibiae; metasoma less matellic than head and thorax, 4th and following terga with brassy reflection. Wings distinctly brownish ; tegulae brownish subhyaline with green tint. 
Hairs on head and thorax white or whitish, more or less long ; 1st tergum hairy, hairs on apical portion patch-like, white, those on medio-apical portion directed toward the head ; hairs on apical portion of metasoma long, fuscous, not dense.

TYPe MATERIAL : Holotype female (BISHOP 14327), Bulldog Road, ca $14 \mathrm{~km} \boldsymbol{S}$ of Edee Creek, near Wau, Papua New Guinea, 2,400 m, 4-10. VII. 1966 (G. A. Samuelson), in the collection of Bishop Museum.

This species is named in honor of Dr. G. A. Samuelson of Bishop Museum to whom I am grateful for his collaboration to my studies of the Papuan insects.

\section{Palaeorhiza (Callorhiza) albopicta, new species}

This is a small and tri-colored species whose head and thorax are blackish steel-blue with white markings and metasoma is red. The smooth integument is also one of the characteristics of this handsome species.

Female : Length about $7 \mathrm{~mm}$ or less.

Relative head measurements : length, 23.5 ; width, 26.5 ; upper interocular distance, 14.5 ; width of face, 17.0 ; lower interocular distance, 10.0 ; eye length, 20.0 ; length of clypeus, 99.0.

Head more or less round in. front view ; eyes rather large for the size of head ; inner eye margins distinctly converging below except upper portions ; face distinctly convex when the head is seen from side ; upper portion of supraclypeal area between antennal bases more or less narrow, well convex, upper margin not sharply defined (not sharply elevating) ; malar space linear, slightly widened posteriorly ; vertex well convex, strongly slanting behind ocelli.

Collar of pronotum low, narrow, median portion slightly concave ; thorax more or less long, subcylindrical ; propodeal enclosure large, mostly dorsal.

Metasoma well convex medially.

Head shining, with weak and rather sparse punctures on upper portion of supraclypeal area ; mesoscutum nearly smooth, well shining, with rather strong and more or less dense punctures; scutellum with a little weaker punctures than those on mesoscutum ; metanotum smooth and nearly impunctate ; propodeal enclosure smoother than metanotum, distinctly shining, impunctate ; propodeum lateral to enclosure smooth, shining, with very weak punctures ; pre- and meso-episterna shining, with weak and sparse punctures. Metasoma with 1st tergum smooth, very shining, impunctate ; 2 nd nearly as in 1 st ; impunctate apical margins of 3rd to 5th terga well indicated as in 1 st and 2nd.

Head and thorax shining, blackish steel-blue with slight purple tint as seen in a certain angle ; mandibles shining black; head and thoax with following markings white : median stripe on clypeus, stripe on supraclypeal area, lateral stripe on face along eye margin (upper end not reaching level of mid ocellus), longer stripe on genal area along eye margin, spot lateral to lateral ocellus (rarely disappearing), band on pronotum (often narrowed or interrupted in the middle), spot on axilla (rarely absent), lateral stripe on scutellum (rarely absent), lateral spot on metanotum, lateral stripe on propodeal enclosure (rarely absent), apical half of tubercle, spot on upper portion of pre-episternum and short band on upper portion of metepistemum ; mesoscutum rarely with a pair of white stripes. Wings slightly dusky ; tegulae ferruginous subhyaline. Legs brownish ; all tarsi more paler; fore tibiae pale yellow or whitish anteriorly ; mid and hind tibiae with basal pale yellow or whitish marks ; apices of all femora whitish. Metasoma red, shining ; extreme base of 1st tergum black ; 6th tergum and sternum blackened.

Hairs on head, thorax and legs whitish, short ; those on mesoscutum shining brown as seen in a certain angle ; lateral and posterior faces of propodeum densely covered with very short, white hairs. 
Hairs on 3rd and 4th metasomal terga ferruginous ; those on 6th tergum and sternum blackish.

Male : Similar to female except as follows :

Smaller ; inner eye margins more strongly converging below ; clypeus flat, hardly convex when the head is seen from side ; scape short, shorter than first three segments of flagellum taken together, rather flattened ; 1st and 2nd flagellar segments ring-like ; 3rd segment longer than broad, about as long as 1 st and 2 nd taken together. White markings on the head and thorax more developed ; mandibles, labrum, clypeus, paraocular area and anterior face of scape white ; white mark on supraclypeal area reduced to a spot on upper portion ; mesepistemum with transverse band medially. Metasomal sterna unmodified.

TYPE MATERIAL : Holotype female (BISHOP 14328), Baiyer River, 1,100 m, W. H. D., Papua New Guinea, 1-5. IX. 1969 (Y. Hirahima) ; 6 females and 1 male, Wau, 1,250 m, Morobe District, Papua New Guinea, 1961-65, collected by J. Sedlacek and L. W. Quate ; all in the Bishop Museum.

\section{Palaeorhiza (Callorhiza) fulvago, new species}

This is a small, slender, cylindrical and yellow species with black markings on the head and thorax and reddish tint on the metasoma. The integument is smooth and very shining. The recognition of this species is easy because of the coloration and the structure of thorax.

Female : Length about or less than $6 \mathrm{~mm}$.

Relative head measurements : length, 23.0 ; width, 25.0 ; upper interocular distance, 14.0 ; width of face, 17.0 ; lower interocular distance, 10.5 ; length of eye, 19.0 ; length of clypeus, about 9.0.

Head rather round as seen in front ; inner eye margins distinctly converging below except upper portions ; as seen from side, face distinctly convex ; upper portion of supraclypeal area broad ; malar space linear anteriorly, slightly widened posteriorly ; vertex well convex.

Thorax elongate, cylindrical, with dorsal portion flat ; scutellum, metanotum and most part of dorsal portion of propodeum flat ; thus, propodeum elongate, with large, dorsally flat enclosure.

Metasoma long, subcylindrical.

Head smooth, very shining, with weak punctures on vertex ; mesoscutum very smooth and shining, with sparse, rather weak punctures ; scutellum and metanotum similar to mesoscutum but punctures weaker; propodeal enclosure smooth, impunctate, shining ; sides of thorax smooth with very weak, rather dense punctures except lateral face of propodeum minutely and very closely punctate. Metasoma smooth, shining ; 1st tergum impunctate ; 2 nd with very weak, sparse punctures ; 3rd with punctures more distinct.

Head pale yellow, with black markings on frons and vertex ; margins of clypeus brown; apex of mandible red. Scape yellow except apex ; flagellum yellowish beneath, brown above. Thorax pale yellow with black stripes as shown in Plate I, Fig. 2 ; median black stripe extending to propodeal enclosure. Wings subhyaline ; tegulae yellowish ferruginous hyaline. Legs yellow ; all tarsi slightly brownish. Metasoma yellow, slightly reddened dorsally ; apex of 5th tergum slightly darkened.

Hairs inconspicuous ; hairs on thorax short, sparse, mostly whitish ; hairs on apical portion of metasoma brownish.

Male : Smaller but similar to female except as follows :

Eyes very large with inner margins very strongly converging below ; clypeus flat, not at all convex as seen from side of head ; scape short, swollen ; flagellum distinctly swollen toward apical segment ; sterna unmodified ; apical sterna without hair fringe ; black marking more developed on face (lower portion of supraclypeal area and upper portion of clypeus black).

TYPE MATERIAL: Holotype female (BISHOP 14329), 17 paratopotype females and 3 paratopotype males, Baiyer River Sanctuary, 1,200 m, W. H. D., Papua New Guinea, 4-8. VIII. 1982 (Y. Hirashima), 
in the collection of Kyushu University.

\section{Palaeorhiza (Callorhiza) attractans, new species}

This is a more or less small species with rich yellow maculations on the thorax. The yellow marking is present even on the propodeal enclosure. So far as the thoracic yellow maculation is concerned, this species is similar to P. (Cnemidorhiza) variablis Hirashima, but this species is subgenetically different.

Female : Length, about $7 \mathrm{~mm}$; forewing length, about $6 \mathrm{~mm}$.

Relative head measurements : length, 27.0 ; width, 30.0 ; upper interocular distance, 16.0 ; width of face, 20.0 ; lower interocular distance, 14.5 ; eye length, 22.0 ; clypeal length, 11.5.

Inner eye margins more or less distinctly converging below except upper portions ; face well convex in front ; supraclypeal area well convex but broadly flat ; malar space about half as long as basal width of mandible posteriorly, well indicated by yellow. Thorax more or less long, cylindrical ; collar of pronotum rather concave medially ; scutellum broad, flat; metanotum also flat ; propodeal enclosure typical for the subgenus. Three basal metasomal terga large, well convex dorsally.

Punctures on face weak ; those on upper portion of head more or less distinct ; frons just above antenna1 sockets largely impunctate; punctures on mesoscutm and scutellum rather dense, not strong ; those on sides of thorax weaker and sparser than those on mesoscutum. Metasoma smooth, strongly shining ; 1st tergum nearly impunctate; broad, impunctate, apical margins of three basal terga well indicated.

Head and thorax slightly coppery and green, with rich yellow markings or portions as follows : paraocular areas, a broad median stripe on face, labrum, mandibles except tips, malar space, most part of genal area, mark on ocellocular space connected with mark on paraocular area, a narrow band on vertex along preoccipital carina, entire band on pronotum, four stripes on mesoscutum, triangular mark on axilla, lateral large marks on scutellum, metanotum and propodeal enclosure, mark on lower portion of pronotum connected with tubercle (which is also yellow), two transverse bands on side of thorax (the upper band extending to upper portion of lateral face of propodeum), and a pair of marks on underside of thorax before coxae of midlegs; tegular pale ferruginous hyaline ; legs red with yellow markings on basal portions ; metasoma with three basal terga and sterna red, three apical terga and sterna violet; apical margin of 3rd tergum also broadly violet ; small laterobasal marks on 3rd tergum yellow; three apical sterna each with a distinct yellow band basally.

Hairs on head and thorax sparse, short, whitish ; white hairs on propodeum not specially dense ; hairs on legs golden; hairs on violet portions of metasoma black or nearly so.

Type material: Holotype female (BISHOP 14330), 3 paratopotype females, Kuk, 1,600 m, near Mt. Hagen, Papua New Guinea, 12-13. VIII. 1982 (Y. Hirashima), in the collection of Kyushu University ; 1 paratype female, Goroka, 1,530 m, Papua New Guinea, 28. IV. 1959 (C. D. Michener), in the collection of Bishop Museum.

N OtE: The paratopotypes are smaller than the holotype., The holotype female and 3 paratopotype females were collected on the flowers of Hybiscus by me.

\section{Palaeorhiza (Callorhiza) micheneri, new species}

This 'is a medium-sized, robust, largely yellow species, but the metasoma is red (or reddish ferruginous) on three basal segments and dark metallic purple on three apical segments. This species is easily recognized by the propodeal enclosure entirely or nearly entirely yellow.

Female : Length about $8 \mathrm{~mm}$. 
Relative head measurements: length, 32.0 ; width, 34.5 ; upper interocular distance, ca 17.0 ; width of face, 22.0 ; lower interocular distance, 16.5 ; eye length, 26.0 ; length of clypeus, 14.0.

Inner eye margins slightly converging below except upper portion ; malar space long, about twothirds as long as basal width of mandible ; face well convex ; supraclypeal area well convex, well elevating between antennae, upper limit not sharp. Callor of pronotum thick, well elevated ; mesoscutum not highly convex ; scutellum flat, not specially large ; propodeal enclosure more or less short, slanting. Wing with 2nd submarginal cell rather small, receiving both recurrent veins near ends. Metasoma well convex as usual.

Head nearly impunctate except frons and upper portion with dense, small punctures; mesoscutum distinctly and densely punctate; scutellum similar to mesoscutum but punctures weaker; propodeal enclosure nearly smooth, impunctate ; sides of thorax very densely punctate. Metasomal terga smooth, very shining, with minute, sparse punctures.

Head yellow except as follows : lateral stripes on clypeus, narrow apical margin of clypeus and malar space ferruginous or red ; frons (except median yellow stripe) and vertex black. Antennae with scape ferruginous, flagellum brownish above, reddened beneath. Thorax yellow except as follows: three stripes on mesoscutum black ; antero-lateral margin of mesoscutum lateral to tubercle black ; broad median stripe on scutellum black ; dorsal face of propodeum lateral to enclosure ferruginous ; interrupted transverse line on side of thorax black ; and lateral corners of collar of pronotum black ; black thoracic markings partly reddened or red in the paratype. Wings subhyaline. Legs yellow, with tarsi slightly reddened. Metasoma red (or reddish ferruginous) on three basal segments and dark metallic purple on three apical segments ; large lateral yellow patches on three basal terga basally.

Hairs inconspicuous, white or whitish ; hairs on three apical segments of metasoma black.

Type materiat : Holotype female (BISHOP 14331) and 1 paratopotype female, Bubia, near Lae, Papua New Guinea, 21. V. 1959 (C. D. Michener), in the collection of Bishop Museum.

This species is named in honor of Professor Charles D. Michener of the University of Kansas, Lawrence, U. S. A., a distinguished entomologist and a leading hymenopterologist of the world.

\section{Palaeorhiza (Callorhiza) agrias, new species}

This is a medium-sized, robust, yellow-fulvous species with metallic colloration on the metasoma. No black marking on the thorax, which is exceedingly densely punctate.

Female: Length about or a little less than $8 \mathrm{~mm}$.

Relative head measurements : length, 31.5 ; width, 36.2 ; upper interocular distance, 18.0 ; width of face, 23.0 ; lower interocular distance, 17.0 ; eye length, 27.0 ; length of clypeus, 14.0.

Inner eye margins slightly converging below except upper portions; upper portion of supraclypeal area between antennal bases well convex, more or less gently reducing its height above ; face rather flat when the head is seen from side ; malar space well indicated, about one-third as long as basal width of mandible ; vertex transverse when the head is seen in front ; vertex behind ocelli strongly slanting. Scape long; flagellum rather long.

Thorax robust ; collar of pronotum well convex and upper margin arched as seen in front ; mesoscutum, scutellum and metanotum well convex ; median portion of propodeum including most part of propodeal enclosure well convex.

Metasoma well convex dorsally.

Face microscopically lineolate, therefore more or less dull, with very weak, sparse punctures; punctures on upper portion of frons more or less distinct ; thorax rather dull ; mesoscutum exceedingly densely, rather strongly punctate ; scutellum punctate like mesoscutum ; metanotum very densely punctate, punctures much weaker than those on scutellum ; propodeal enclosure microscopically 
granular, dull, impunctate ; propodeum lateral to enclosure rather strongly punctate ; pre- and mesoepistema dull, exceedingly densely punctate like mesoscutum, Metasoma with 1st tergum nearly smooth, shining, almost impunctate ; 2nd tergum microscopically lineolate, with indication of sparse, very weak punctures; 3 rd tergum more lineolate and punctate than 2 nd ; 4th and following terga shagreened, dull.

Head pale yellow ; frons and vertex pale fulvous ; apical margin of mandible red. Scape yellow except apex ; flagellum brown above, paler below. Thorax with upper portion of pronotum, mesoscutum, scutellum, metanotum and dorsal face of propodeum fulvous or paler, lateral and lower portions yellow ; posterior face of propodeum also pale yellow ; collar of pronotum with transverse, evanescent yellow band ; mesoscutum with four longitudinal, evanescent yellow stripes. Wings more or less darkened; tegulae ferruginous subhyaline. Legs yellow ; tarsi slightly darkened. Metasoma variably colored ; basal portions of 1st to 4th terga pale yellow or whitish ; median portions of 1 st and 2nd terga fulvous ; most part of 2nd tergum piceous with metallic steel blue and purple tints ; 3rd to 5th terga distinctly metallic steel blue and purple ; 6th tergum blackish ; 1 st sternum, most part of 2nd sternum and median and basal portions of 3rd sternum pale yellow or whitish ; 4th and 5th sterna with basal halves pale and apical halves metallic like corresponding terga ; 6th sternum largely pale with apical portion brown.

Hairs on head and thorax not conspicuous, whitish ; hairs on legs pale and golden ; hairs on apical portion of metasoma black or nearly so.

Type Material: Holotype female (BISHOP 14332), Torricelli Mts., Sugoitei VIII., Papua New Guinea, 24. I.-5. II. 1959 (W. W. Brandt), in the collection of Bishop Museum.

\section{Explanation of Plate I}

$1:$ Palaeorhiza (Callorhiza) attractans, new species

2: Palueorhiza (Callorhiza) fulvago, new species

$3:$ Palaeorhiza (Callorhiza) micheneri, new species

4 : Palaeorhiza (Callorhiza) agrias, new species

5: Palaeorhiza (Callorhiza) albopicta, new species

6: Palueorhiza (Callorhiza) samuelsoni, new species

7: Palueorhiza (Callorhiza) bagudai Cheesman

8 : Palaeorhiza (Callorhiza) disrupta Cockerell 
ESAKIA, №. 28, 1989
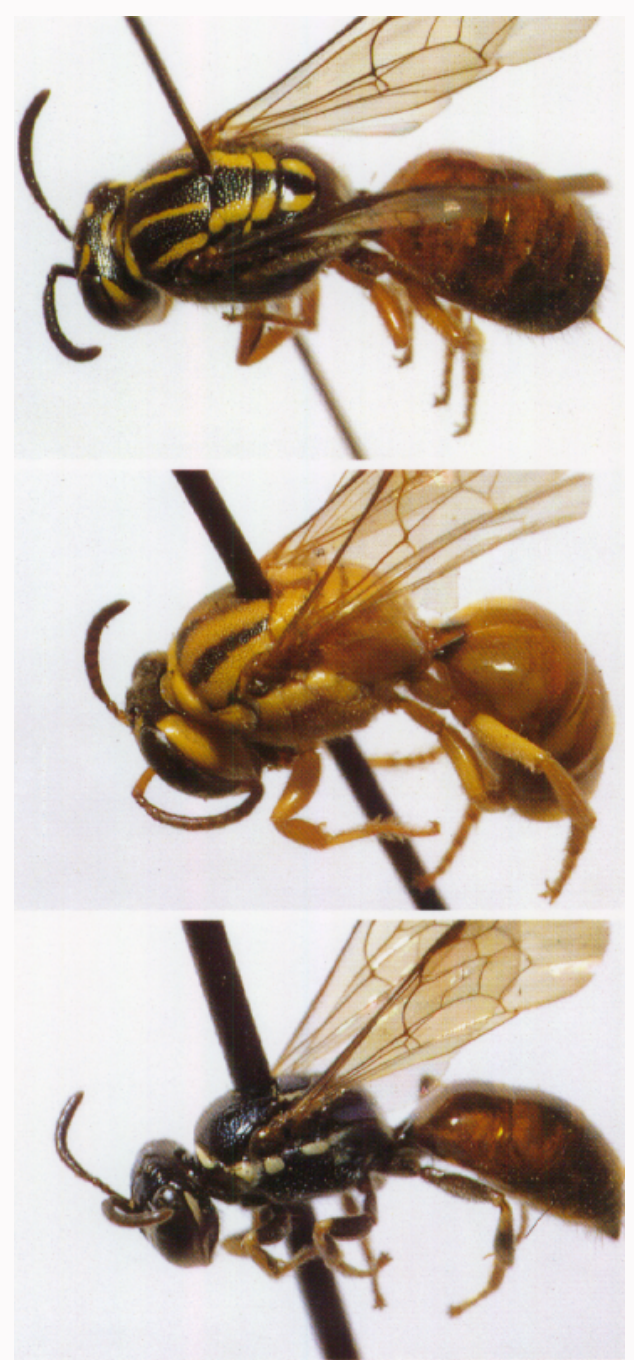

3

5
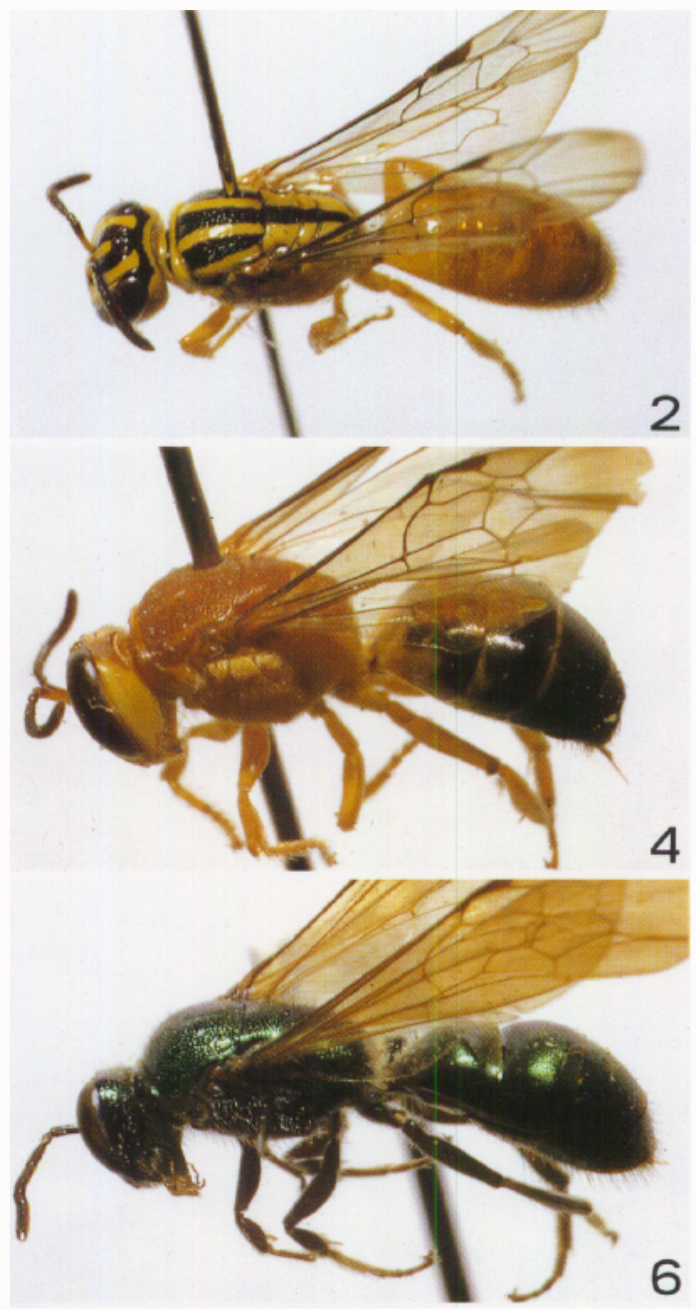

2

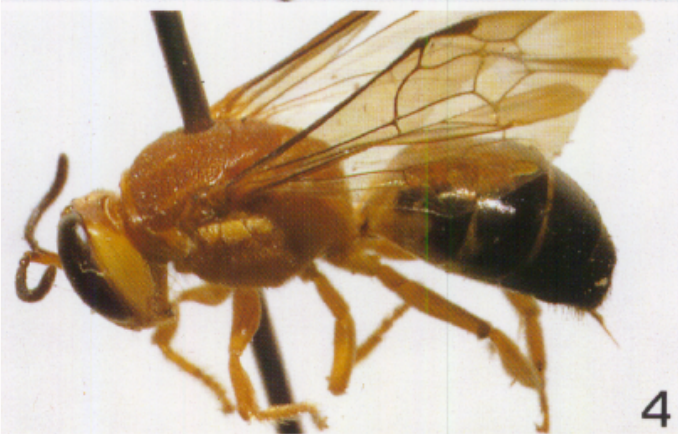

4

6

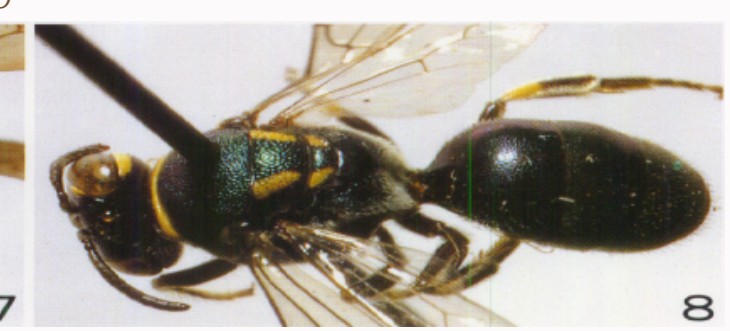

